\author{
죽초액을 급여한 돼지고기의 저장 중 육질특성 변화 \\ 국 길·김광현 \\ 전남대학교 농업과학기술연구소 동물자원학부
}

\title{
Changes in Meat Quality Characteristics on Refrigerated Pork Loin Fed with Supplemental Bamboo Vinegar
}

\author{
K. Kook and K. H. Kim \\ Division of Animal Science, Institute of Agricultural Science and Technology, Chonnam National \\ University, Gwangju 500-757, Korea
}

\begin{abstract}
This experiment was conducted to investigate the changes in meat quality characteristics on refrigerated $\left(4^{\circ} \mathrm{C}\right)$ pork loin fed with supplemental levels of Bamboo vinegar(BV). Thirty pigs were divided into 3 groups of 10 pigs. Dietary levels of Bamboo vinegar $0 \%$ (control), $2 \%$ and $4 \%$ were included in experimental diets of each of the groups. The $\mathrm{pH}$ value was decreased $(\mathrm{P}<0.05)$ in $2 \%$ and $4 \% \mathrm{BV}$ compared to the control after $3 \mathrm{~d}$ of storage. Lightness was increased $(\mathrm{P}<0.05)$ in $2 \%$ and $4 \% \mathrm{BV}$ compared to the control at $1 \mathrm{~d}$ and $3 \mathrm{~d}$. Redness was decreased $(\mathrm{P}<0.05)$ in $4 \% \mathrm{VB}$ compared to the control at $1 \mathrm{~d}$ and $3 \mathrm{~d}$. The $2 \%$ and $4 \%$ BV showed a significant $(\mathrm{P}<0.05)$ increase in yellowness throughout the whole experiment compared to control. Cooking loss was increased $(\mathrm{P}<0.05)$ in $2 \%$ and $4 \%$ BV compared to the control after $3 d$ of storage. Shear force was decreased $(P<0.05)$ in $2 \%$ and $4 \%$ BV compared to control at $1 \mathrm{~d}$ and $3 \mathrm{~d}$. TBA was decreased $(\mathrm{P}<0.05)$ in $2 \%$ and $4 \%$ BV at $6 \mathrm{~d}$ and $9 \mathrm{~d}$. Total microbial counts was decreased $(\mathrm{P}<0.05)$ in $2 \%$ and $4 \%$ BV compared to control. The $2 \%$ and $4 \%$ BV scored higher $(\mathrm{P}<0.05)$ in odor evaluation compared to the control at $1 \mathrm{~d}$ and $3 \mathrm{~d}$. The $2 \%$ and $4 \%$ BV also scored higher $(\mathrm{P}<0.05)$ than the control in the evaluation of appearance at $1 \mathrm{~d}$. The taste was increased $(\mathrm{P}<0.05)$ in $2 \%$ and $4 \% \mathrm{BV}$ compared to control at $1 \mathrm{~d}, 3 \mathrm{~d}$, and $6 \mathrm{~d}$. These results showed that the addition of $2 \%$ or $4 \% \mathrm{BV}$ improved the meat quality and storage characteristics of refrigerated pork. (Key words : Bamboo vinegar, Pork lion, Meat quality, TBA, Total microbial counts)
\end{abstract}

\section{I. 서 론}

수입개방과 IMF 외환위기로 어려움에 직면 하고 있는 축산농가들은 값싸고 대량으로 들어 올 수입육과의 차별화를 위해 우리나라 정서에 맞고 지역 특색을 강조한 고품질 브랜드 축산 물만이 앞으로 우리 나라 시장에 있을 무차별 적인 수입공세에 어느 정도의 우리시장은 지켜
나갈 수 있을 것으로 대부분 판단하고 있다. 소비자 또한 우수한 육질과 위생적인 고기에 관심이 높아지면서 점차 소비자들에게 건강적 인 이미지와 지역 특색을 강조한 기능성 브랜 드육을 선호하는 경향을 보이고 있다.

죽초액은 전남 담양지역의 특산물인 대나무 및 그 부산물을 탄화시켜 얻어진 수용성 액체 로써 초산과 같은 유기산, 페놀류 등의 2 백여

Corresponding author : K. Kook, Division of Animal Science, Institute of Agricultural Science and Technology, Chonnam National University, Gwangju 500-757, Korea. E-mail : kkuk21@hanmail.net 
종의 미량 화합물로 구성되어 있다고 보고되고 있다(Hisasi, 1993; Akio, 1993). 죽초액은 예로 부터 우리 조상들의 민간요법으로 위장병 치료 에 많이 이용되어 왔으며 동의보감, 본초강목, 향약집성방 등의 고전 한의서에 의하면 사람이 직접 음용시 강장작용과 항암효과, 숙취제거, 위장장애, 당뇨, 간질환, 성기능 강화, 변비, 어 혈 등을 풀어주고 각종 질병예방에 효능이 있 는 물질로 알려져 왔다(김과 김, 1998). 농축산 업분야에서 토양개량제, 식물생장촉진제, 가축 사료 보조제 및 질병 치료제 등 다양한 용도로 연구되고 있다(김, 1990; 석과 장, 1999; 석 등 1998; 장과 석, 2001). 특히 谷田具光克(1990) 에 의하면 죽초액이 암모니아나 유황화합물 등 의 냄새 성분을 중화 또는 마스킹이라 불리는 화학적 작용으로 악취가 없는 물질로 변화시켜 소취작용을 한다고 보고하고 있다. 그러나, 죽 초액에 대한 구체적인 연구보고는 전무한 실정 이다. 이와 유사한 목탄액(목초액)은 국외에서 의료, 식품, 사료 및 환경개선 등에 적용이 가 능하다고 하였다(福島, 1980; 松田, 1975, 田村, 1975; 永田, 1983). 福島(1980)은 목탄액이 젖 소의 위액과 VFA에 미치는 영향을 구명하였으 며, 류 등(1997)는 목탄과 목탄액을 육계의 생 산성과 육질에 미치는 영향을 보고하였다. 그 러나, 비육돈에 대한 죽초액의 이용에 관한 구 체적인 연구보고는 전무한 실정이다.

따라서 본 연구는 육성비육돈에 죽초액을 $0 \%, 2 \%$ 및 $4 \%$ 수준으로 2 개월간 급여한 돼지 고기의 저장중 육질특성의 변화에 미치는 영향 을 알아보고자 실시하였다.

\section{ㅍ. 재료 및 방법}

\section{1. 공시재료}

본 시험은 평균체중 $60 \pm 1.5 \mathrm{Kg}$ 인 3 원 교잡종 (Landrace $\times$ Yorkshire $\times$ Duroc) 육성비육돈 30 두를 대조구(control)와 죽초액 $2 \%$ 급여구 $(2 \%$ $\mathrm{BV})$, 죽초액 $4 \%$ 급여구 $(4 \% \mathrm{BV})$ 의 3 개 처리구 로 공시하였으며, 전남 담양군 수북면 고성리 채천기 농장에서 2001년 9월부터 2001년 10월
까지 2개월 동안 사육하여 농협 나주축산물 공 판장에 출하하여 도축한 후 등심육을 채취하여 시료로 이용하였다.

\section{2. 시험설계}

도축 후 냉각실에서 $4.0 \pm 1.5^{\circ} \mathrm{C}$ 상태로 24시 간 냉각된 도체의 등심육을 시료로 채취하여 스테이크 모양으로 절단(두께 $2.0 \mathrm{~cm})$ 한 후 지 퍼백에 넣어 $4.0 \pm 1.5^{\circ} \mathrm{C}$ 에서 $1,3,6$ 및 9일간 저장하였다.

3. 시험방법

(1) $\mathrm{pH}$

pH는 Skin $\mathrm{pH}$ meter(Orion, model 520A, U. S. A)를 이용하여 측정하였다.

(2) 육색

육색은 포장을 개봉한 후 30 분간 홍색화 (blooming)를 실시하고 표면의 수분을 적당히 제거하여 Chroma meter(Minolta Co, CR-301)로 명도 $(\mathrm{L})$, 적색도(a) 및 황색도(b)를 측정하였다. 이때 표준판은 $\mathrm{Y}=92.40, \mathrm{x}=0.3136, \mathrm{y}=0.3196$ 의 백색타일을 사용하였다.

\section{(3) 가열감량}

스테이크 모양으로 절단된 시료를 진공포장 한 후 육의 내부온도가 $70^{\circ} \mathrm{C}$ 에서 10 분간 유지 되도록 가열한 다음 가열전후의 중량 차로 계 산하였다.

\section{(4) 전단력}

스테이크 모양으로 절단된 시료를 진공포장 한 후 육의 내부온도가 $70^{\circ} \mathrm{C}$ 에서 10 분간 유지 되도록 가열한 후 $5^{\circ} \mathrm{C}$ 이하 냉장고에서 1 시간 방치한 후 직경 $1.8 \mathrm{~cm}$ 코아로 근섬유방향으로 시료를 제조한 다음 전단력 측정기(Texture Analyzer, TA-XT2, Stable Micro Systems, Hasemere, England)로 측정하였다.

(5) 지방산패도 
산패도는 TBA(thiobarbituric acid) test(Witte 등, 1970)로 측정하였으며, TBA 수치는 malonaldehyde $\mathrm{mg} / 1,000 \mathrm{~g}$ 시료의 값으로 표시하였다.

(6) 총균수

총미생물 수는 연속희석시킨 시료를 표준평 판수 배지에 접종하여 $32^{\circ} \mathrm{C}$ 에서 48 시간 배양한 후 $\log _{10} \mathrm{CFU}$ (colony forming units)/1g 시료로 측정하였다(Kotula 등, 1980).

\section{(7) 관능평가}

훈련된 관능검사요원 15 명중 10 명을 무작위 로 추출하여 시료의 냄새, 외관 및 맛 등의 기 호도를 9점 척도법(9 point hedonic scale)에 준 하여 평가하였다 $(9=$ 가장 좋다; $8=$ 대단히 좋다; $7=$ 보통으로 좋다; $6=$ 약간 좋다; $5=$ 좋지도 싫지 도 않다; $4=$ 약간 싫다; $3=$ 보통으로 싫다; $2=$ 대 단히 싫다; $1=$ 가장 싫다).

\section{4. 통계분석}

본 시험에서 얻어진 자료의 통계처리는 SAS $\operatorname{program}(1988)$ 을 분산분석과 t-test를 실시하여 상호간의 통계적인 차이를 분석하였다.

\section{III. 결과 및 고찰}

\section{1. $\mathrm{pH}$ 의 변화}

죽초액을 급여한 돼지고기의 저장 중 $\mathrm{pH}$ 의 변화는 Table 1에 나타낸 바와 같다. 돼지고기
의 $\mathrm{pH}$ 는 저장 1 일에는 처리간에 유의적인 차 이는 없었지만 저장 3 일부터는 죽초액 $2 \%$ 와 $4 \%$ 급여구가 대조구에 비해 유의적 $(\mathrm{P}<0.05)$ 으 로 감소함을 나타냈다. 특히 죽초액 $4 \%$ 급여구 가 저장기간 동안 완만한 $\mathrm{pH}$ 의 변화를 나타내 어 돼지고기의 저장 안정성을 향상시킨 것으로 사료된다. 일반적으로 $\mathrm{pH}$ 는 저장기간이 경과할 수록 증가하는데 이는 저장기간이 진행됨에 따 라 유리 아미노산의 생성, 단백질 완충물질의 변화, 전해질 해리의 감소 및 암모니아의 생성 에 그 원인이 있으며(Deymer와 Vandekerckhove, 1979), 지방의 산패에 따른 과산화물의 축적이나 단백질 분해에 의한 암모니아 생성 (박 등, 1997)이나 당과 지방이 분해되어 유기 산, 알데하이드, 케톤, 알코올, 카보닐 등이 생 성되어(Ketelaere 등, 1974) $\mathrm{pH}$ 에 영향을 미치기 때문이다(Khan과 Van den Berg, 1964; Field와 Chang, 1969; 박 등, 1988).

2. 육색의 변화

죽초액을 급여한 돼지고기의 저장 중 육색의 변화는 Table 2에 나타낸 바와 같다. 육색은 소 비자의 기호도를 결정하는 것인데 죽초액의 급 여에 의한 명도 $(\mathrm{L})$ 는 저장 1 일과 3 일에 $2 \%$ 와 $4 \%$ 급여구가 대조구에 비해 유의적 $(\mathrm{P}<0.05)$ 으 로 높게 나타났으며 저장 6일과 9일에도 비교 적 높은 경향이였다. 적색도는 저장기간 동안 $2 \%$ 와 $4 \%$ 급여구에서 감소하는 경향이였는데 저장 1 일과 3 일에 죽초액 급여구에서 대조구에 비해 유의적인 $(\mathrm{P}<0.05)$ 차이를 나타냈다. 황색

Table 1. Changes in $\mathrm{pH}$ values on refrigerated pork loin fed with supplemental Bamboo vinegar

\begin{tabular}{cccc}
\hline Storage days & Control & $2 \%$ BV & $4 \%$ BV \\
\hline \hline $1 \mathrm{~d}$ & $5.76 \pm 0.01^{1)}$ & $5.60 \pm 0.01$ & $5.54 \pm 0.02$ \\
$3 \mathrm{~d}$ & $5.92 \pm 0.05^{\mathrm{a}}$ & $5.60 \pm 0.02^{\mathrm{b}}$ & $5.58 \pm 0.03^{\mathrm{b}}$ \\
$6 \mathrm{~d}$ & $5.94 \pm 0.04^{\mathrm{a}}$ & $5.61 \pm 0.02^{\mathrm{ab}}$ & $5.59 \pm 0.01^{\mathrm{b}}$ \\
$9 \mathrm{~d}$ & $6.15 \pm 0.07^{\mathrm{a}}$ & $5.82 \pm 0.05^{\mathrm{b}}$ & $5.62 \pm 0.02^{\mathrm{c}}$ \\
\hline
\end{tabular}

1) Means \pm SD

${ }^{a, b, c}$ Means in the same row with different superscripts significantly differ $(\mathrm{P}<0.05)$. 
Table 2. Changes in meat color on refrigerated pork loin fed with supplemental Bamboo vinegar

\begin{tabular}{ccccc}
\hline & & Control & $2 \%$ BV & $4 \%$ BV \\
\hline \hline \multirow{3}{*}{ Lightness(L) } & & $46.0 \pm 0.26^{1)}$ & $50.8 \pm 0.49^{\mathrm{a}}$ & $48.5 \pm 0.92^{\mathrm{a}}$ \\
& $1 \mathrm{~d}$ & $48.3 \pm 0.94^{\mathrm{b}}$ & $51.0 \pm 0.84^{\mathrm{a}}$ & $50.3 \pm 1.18^{\mathrm{a}}$ \\
& $3 \mathrm{~d}$ & $51.3 \pm 0.87$ & $53.6 \pm 1.16$ & $53.3 \pm 1.04$ \\
& $6 \mathrm{~d}$ & $53.7 \pm 0.92$ & $54.9 \pm 0.93$ & $54.1 \pm 0.30$ \\
\hline \multirow{3}{*}{ Redness(a) } & $9 \mathrm{~d}$ & $7.8 \pm 0.26^{\mathrm{a}}$ & $6.5 \pm 0.27^{\mathrm{b}}$ & $6.3 \pm 0.26^{\mathrm{b}}$ \\
& $1 \mathrm{~d}$ & $6.9 \pm 0.68^{\mathrm{a}}$ & $6.1 \pm 0.46^{\mathrm{a}}$ & $5.8 \pm 0.40^{\mathrm{b}}$ \\
& $3 \mathrm{~d}$ & $5.7 \pm 0.20$ & $5.3 \pm 0.37$ & $4.9 \pm 0.40$ \\
& $6 \mathrm{~d}$ & $4.9 \pm 0.24$ & $4.3 \pm 0.45$ & $4.2 \pm 0.18$ \\
\hline \multirow{3}{*}{ Yellowness(b) } & $9 \mathrm{~d}$ & $5.5 \pm 0.35^{\mathrm{b}}$ & $6.8 \pm 0.37^{\mathrm{a}}$ & $6.3 \pm 0.36^{\mathrm{ab}}$ \\
& $1 \mathrm{~d}$ & $5.4 \pm 0.44^{\mathrm{b}}$ & $6.6 \pm 0.32^{\mathrm{a}}$ & $6.6 \pm 0.53^{\mathrm{a}}$ \\
& $3 \mathrm{~d}$ & $5.8 \pm 0.33^{\mathrm{b}}$ & $6.9 \pm 0.25^{\mathrm{a}}$ & $6.8 \pm 0.34^{\mathrm{a}}$ \\
& $6 \mathrm{~d}$ & $5.9 \pm 0.39^{\mathrm{b}}$ & $6.5 \pm 0.52^{\mathrm{a}}$ & $6.5 \pm 0.27^{\mathrm{a}}$ \\
\hline
\end{tabular}

1) Means $\pm \mathrm{SD}$.

${ }^{a, b}$ Means in the same row with different superscripts significantly differ $(\mathrm{P}<0.05)$.

도는 죽초액을 급여함으로서 저장기간 동안 대 조구에 비해 유의적 $(\mathrm{P}<0.05)$ 으로 높게 나타났 다. 육색은 소비자가 돈육을 구매할 때 신선도 의 기준으로서 가장 중요하게 여기는데, 육색 은 일반적으로 근육중에 함유된 색조단백질인 myoglobin의 양과 상태에 따라 다르게 나타냈 는데(Lizaso 등, 1996), myoglobin이 산소와 결 합하면 oxymyoglobin으로 되어 선홍색을 띠나 시간이 경과하면 산화되어 metmyoglobin으로 되어 암갈색을 띠게 된다(Ledward, 1984)고 알 려졌다.

\section{3. 가열감량의 변화}

죽초액을 급여한 돼지고기의 저장 중 가열감 량의 변화는 Table 3 에 나타낸 바와 같다. 저장 1 일에는 처리간에 차이는 없었지만 저장 3 일과 6일에 죽초액 급여구가 대조구에 비해 유의적 $(\mathrm{P}<0.05)$ 으로 높았다 저장 9 일에는 $4 \%$ 급여구 가 유의적인 $(\mathrm{P}<0.05)$ 차이를 나타냈다. 일반적 으로 돈육의 가열감량은 저장기간이 경과함에 따라 함유수분의 유출량이 증가하며, Palanska 와 Nosal (1991)은 식육의 $\mathrm{pH}$ 가 높으면 가열감 량이 감소한다고 하였다. 따라서 본 연구에서

Table 3. Changes in cooking loss on refrigerated pork loin fed with supplemental Bamboo vinegar

$(\%)$

\begin{tabular}{cccc}
\hline Storage days & Control & $2 \%$ BV & $4 \%$ BV \\
\hline \hline $1 \mathrm{~d}$ & $21.43 \pm 0.65^{1)}$ & $22.56 \pm 0.59$ & $22.37 \pm 0.81$ \\
$3 \mathrm{~d}$ & $23.43 \pm 0.63^{\mathrm{b}}$ & $25.16 \pm 1.62^{\mathrm{a}}$ & $26.42 \pm 0.41^{\mathrm{a}}$ \\
$6 \mathrm{~d}$ & $25.48 \pm 0.63^{\mathrm{b}}$ & $28.09 \pm 1.25^{\mathrm{a}}$ & $27.19 \pm 0.39^{\mathrm{a}}$ \\
$9 \mathrm{~d}$ & $27.62 \pm 0.54^{\mathrm{b}}$ & $27.72 \pm 0.86^{\mathrm{b}}$ & $29.01 \pm 0.57^{\mathrm{a}}$ \\
\hline
\end{tabular}

1) Means \pm SD.

${ }^{\mathrm{a}, \mathrm{b}}$ Means in the same row with different superscripts significantly $\operatorname{differ}(\mathrm{P}<0.05)$. 
도 죽초액 첨가에 의해 $\mathrm{pH}$ 가 감소하였으며 이 에 의해 가열감량이 증가한 것으로 사료된다.

\section{4. 전단력의 변화}

죽초액을 급여한 돼지고기의 저장 중 전단력 가의 변화는 Table 4에 나타낸 바와 같다. 저장 1 일과 3 일에 $2 \%$ 와 $4 \%$ 급여구가 대조구에 비 해 유의적 $(\mathrm{P}<0.05)$ 으로 낮은 전단력으로 연도 개선효과를 나타냈다. 일반적으로 전단력은 저 장기간이 경과할수록 연도 증가가 개선되는데 이는 일반적으로 사후 $\mathrm{pH}$ 와 온도가 연도에 영 향을 미치며, 주로 근육내 효소들에 의한 근원 섬유단백질 등의 분해로 고기가 연화된다고 하 였다(Yates 등, 1983). 따라서 죽초액의 급여가 근육내 효소나 미생물의 효소에 의해 단백질이 분해되어 조직이 와해되거나 유리아미노산 및 비단백질소화합물의 증가(Khan과 Van den Berg, 1964; Field와 Chang, 1969; 박 등, 1988)에 의 해 전단력이 감소되는 것으로 사료된다.

\section{5. 지방산패도의 변화}

죽초액을 급여한 돼지고기의 저장 중 지방산 패도는 Table 5에 나타낸 바와 같다. 대조구는 저장기간의 경과에 따라 지방산패도가 증가하 는 경향을 나타냈으나, 죽초액 $2 \%$ 와 $4 \%$ 급여 구는 저장기간의 경과에 별다른 변화를 보이지 않았다. 저장일 별로 살펴볼 때 저장 6 일과 9 일에 죽초액 $2 \%$ 와 $4 \%$ 급여구가 대조구에 비 해 유의적 $(\mathrm{P}<0.05)$ 으로 감소함을 나타냈다.

\section{6. 총균수의 변화}

죽초액을 급여한 돼지고기의 저장 중 총균수 의 변화는 Table 6에 나타낸 바와 같다. 돈육 등심 표면의 총균수는 저장기간이 경과함에 따 라 증가하는 경향이었다. 전반적으로 죽초액 $2 \%$ 와 $4 \%$ 급여구가 대조구에 비해 유의적 $(\mathrm{p}<0.05)$ 으로 낮게 나타났다. 일반적으로 육류 내 총균수의 한계치를 $10^{7} \mathrm{CFU} / \mathrm{g}$ 으로 알려져

Table 4. Changes in shear force on refrigerated pork loin fed with supplemental Bamboo vinegar

$\left(\mathrm{kg} / \mathrm{cm}^{2}\right)$

\begin{tabular}{cccc}
\hline Storage days & Control & $2 \%$ BV & $4 \%$ BV \\
\hline \hline $1 \mathrm{~d}$ & $5.51 \pm 0.42^{1 \mathrm{a}}$ & $4.92 \pm 0.35^{\mathrm{b}}$ & $4.80 \pm 0.41^{\mathrm{b}}$ \\
$3 \mathrm{~d}$ & $5.08 \pm 0.21^{\mathrm{a}}$ & $4.53 \pm 0.26^{\mathrm{b}}$ & $4.64 \pm 0.33^{\mathrm{b}}$ \\
$6 \mathrm{~d}$ & $4.14 \pm 0.33$ & $4.07 \pm 0.30$ & $4.41 \pm 0.35$ \\
$9 \mathrm{~d}$ & $4.04 \pm 0.35$ & $4.00 \pm 0.22$ & $4.98 \pm 0.33$ \\
\hline
\end{tabular}

1) Means \pm SD.

${ }^{\mathrm{a}, \mathrm{b}}$ Means in the same row with different superscripts significantly differ $(\mathrm{P}<0.05)$.

Table 5. Changes in TBA on refrigerated pork loin fed with supplemental Bamboo vinegar $(\mathrm{mg} / 1,000 \mathrm{~g})$

\begin{tabular}{clll}
\hline Storage days & Control & $2 \%$ BV & \multicolumn{1}{c}{$4 \%$ BV } \\
\hline \hline $1 \mathrm{~d}$ & $0.30 \pm 0.013^{1)}$ & $0.31 \pm 0.004$ & $0.30 \pm 0.012$ \\
$3 \mathrm{~d}$ & $0.31 \pm 0.014$ & $0.32 \pm 0.006$ & $0.31 \pm 0.014$ \\
$6 \mathrm{~d}$ & $0.36 \pm 0.004^{\mathrm{a}}$ & $0.30 \pm 0.003^{\mathrm{b}}$ & $0.30 \pm 0.005^{\mathrm{b}}$ \\
$9 \mathrm{~d}$ & $0.38 \pm 0.021^{\mathrm{a}}$ & $0.32 \pm 0.004^{\mathrm{b}}$ & $0.32 \pm 0.004^{\mathrm{b}}$ \\
\hline
\end{tabular}

1) Means \pm SD.

a,b Means in the same row with different superscripts significantly differ $(\mathrm{P}<0.05)$. 
Table 6. Changes in total microbial counts on refrigerated pork loin fed with supplemental Bamboo vinegar

$\left(\log _{10} \mathrm{CFU}\right)$

\begin{tabular}{cccc}
\hline Storage days & Control & $2 \%$ BV & $4 \%$ BV \\
\hline \hline $1 \mathrm{~d}$ & $4.58 \pm 0.04^{1 \mathrm{a}}$ & $4.17 \pm 0.02^{\mathrm{b}}$ & $4.22 \pm 0.13^{\mathrm{b}}$ \\
$3 \mathrm{~d}$ & $4.73 \pm 0.07^{\mathrm{a}}$ & $4.35 \pm 0.05^{\mathrm{b}}$ & $4.29 \pm 0.09^{\mathrm{b}}$ \\
$6 \mathrm{~d}$ & $5.18 \pm 0.03^{\mathrm{a}}$ & $4.74 \pm 0.08^{\mathrm{b}}$ & $4.56 \pm 0.03^{\mathrm{b}}$ \\
$9 \mathrm{~d}$ & $7.17 \pm 0.09^{\mathrm{a}}$ & $6.21 \pm 0.03^{\mathrm{b}}$ & $6.16 \pm 0.05^{\mathrm{b}}$ \\
\hline
\end{tabular}

1) Means \pm SD.

${ }^{a, b}$ Means in the same row with different superscripts significantly differ $(\mathrm{P}<0.05)$.

Table 7. Changes in sensory evaluation on refrigerated pork loin fed with supplemental Bamboo vinegar

\begin{tabular}{lllll}
\hline & Items & Control & $2 \%$ BV & $4 \%$ BV \\
\hline \hline \multirow{3}{*}{ Odor } & $1 \mathrm{~d}$ & $5.00 \pm 0.16^{1)^{\mathrm{b}}}$ & $5.85 \pm 0.27^{\mathrm{a}}$ & $6.35 \pm 0.31^{\mathrm{a}}$ \\
& $3 \mathrm{~d}$ & $5.00 \pm 0.13^{\mathrm{b}}$ & $5.45 \pm 0.18^{\mathrm{a}}$ & $5.75 \pm 0.23^{\mathrm{a}}$ \\
& $6 \mathrm{~d}$ & $4.25 \pm 0.31$ & $4.95 \pm 0.42$ & $4.85 \pm 0.33$ \\
& $9 \mathrm{~d}$ & $3.65 \pm 0.42$ & $4.25 \pm 0.30$ & $4.75 \pm 0.38$ \\
\hline \multirow{3}{*}{ Appearance } & $1 \mathrm{~d}$ & $5.00 \pm 0.13^{\mathrm{b}}$ & $5.35 \pm 0.18^{\mathrm{a}}$ & $5.25 \pm 0.27^{\mathrm{a}}$ \\
& $3 \mathrm{~d}$ & $4.85 \pm 0.16$ & $4.85 \pm 0.13$ & $4.95 \pm 0.18$ \\
& $6 \mathrm{~d}$ & $4.50 \pm 0.19$ & $4.80 \pm 0.18$ & $4.75 \pm 0.31$ \\
& $9 \mathrm{~d}$ & $4.15 \pm 0.27$ & $4.25 \pm 0.41$ & $4.50 \pm 0.75$ \\
\hline \multirow{3}{*}{ Taste } & $1 \mathrm{~d}$ & $5.00 \pm 0.23^{\mathrm{b}}$ & $6.63 \pm 0.38^{\mathrm{a}}$ & $7.13 \pm 0.40^{\mathrm{a}}$ \\
& $3 \mathrm{~d}$ & $5.10 \pm 0.14^{\mathrm{b}}$ & $6.75 \pm 0.34^{\mathrm{a}}$ & $7.00 \pm 0.18^{\mathrm{a}}$ \\
& $6 \mathrm{~d}$ & $4.86 \pm 0.18^{\mathrm{a}}$ & $5.15 \pm 0.25^{\mathrm{ab}}$ & $5.35 \pm 0.20^{\mathrm{a}}$ \\
& $9 \mathrm{~d}$ & $4.75 \pm 0.21$ & $5.05 \pm 0.26$ & $5.10 \pm 0.15$ \\
\hline
\end{tabular}

1) Means \pm SD.

a,b Means in the same row with different superscripts significantly differ $(\mathrm{P}<0.05)$.

있는데(Nottingham, 1982), 본 연구결과 죽초액 급여구와 대조구 모두 $10^{6} \mathrm{CFU} / \mathrm{g}$ 이하의 수치 로 위생적인 수준이였으며, 특히 죽초액 급여 구가 보다 더 위생적인 상태임을 알 수 있었 다.

7. 관능평가의 변화

죽초액을 급여한 돼지고기의 저장 중 관능평가
는 Table 7에 나타낸 바와 같다. 냄새는 저장 1 일과 3 일에 죽초액 $2 \%$ 와 $4 \%$ 급여구가 대조구 에 비해 유의적인 $(\mathrm{P}<0.05)$ 차이를 나타내어 돼 지 특유의 이취가 감소하는 효과를 나타냈다. 외관에 있어서도 죽초액의 급여구에서 높은 점 수를 받았는데, 저장 1 일에 죽초액 $2 \%$ 와 $4 \%$ 급여구가 대조구에 비해 유의적인 $(\mathrm{P}<0.05)$ 차이 를 나타냈다. 맛에 있어서도 저장 1 일과 3 일, 6 일에 죽초액 $2 \%$ 와 $4 \%$ 급여구가 대조구에 비 
해 유의적 $(\mathrm{P}<0.05)$ 으로 높은 점수를 받았다.

이상의 결과를 종합해보면 죽초액 $2 \%$ 와 $4 \%$ 급여된 돼지고기는 $\mathrm{pH}$ 의 감소, 육색의 개선, 전단력의 감소, 지방산패도의 감소, 총균수의 감소 그리고 관능평가에서 냄새와 외관, 맛의 개선효과가 있음을 알 수 있었다.

$$
\text { IV. 사 사 }
$$

“본 논문은 농림부의 2001년 농림기술개발과 제(벤처형중소기업기술과제)의 지원으로 수행 되었음"

\section{V. 요 약}

본 연구는 평균체중 $60.0 \pm 1.5 \mathrm{~kg}$ 인 육성비육 돈 30 두를 대조구, 죽초액 $2 \%$ 급여구 및 죽초 액 $4 \%$ 급여구의 3 개 처리구로 10 두씩 배치하 여 4개월간 사양시험을 실시한 후 도축하여 등 심육을 시료로 채취하여 저장 중 육질특성 변 화를 알아보고자 실시하였다.

$\mathrm{pH}$ 는 저장 3 일 이후 죽초액 $2 \%$ 와 $4 \%$ 급여 구가 대조구에 비해 유의적 $(\mathrm{P}<0.05)$ 으로 감소함 을 나타냈다. 명도 $(\mathrm{L})$ 는 저장 1 일과 3 일에 $2 \%$ 와 $4 \%$ 급여구가 대조구에 비해 유의적 $(\mathrm{P}<0.05)$ 으로 높게 나타났다. 적색도는 저장 1 일과 3 일 에 죽초액 $4 \%$ 급여구가 대조구에 비해 유의적 $(\mathrm{P}<0.05)$ 으로 낮게 나타났다. 황색도는 저장기 간 동안 죽초액 $2 \%$ 와 $4 \%$ 급여구가 대조구에 비해 유의적 $(\mathrm{P}<0.05)$ 으로 높게 나타났다. 가열 감량은 저장 3 일 이후 죽초액 $2 \%$ 와 $4 \%$ 급여구 가 대조구에 비해 유의적 $(\mathrm{P}<0.05)$ 으로 높게 나 타났다. 전단력은 저장 1 일과 3 일에 죽초액 $2 \%$ 와 $4 \%$ 급여구가 대조구에 비해 유의적 $(\mathrm{P}<0.05)$ 으로 낮게 나타나 연도 개선효과를 보였다. 지 방산패도는 저장 6 일과 9 일에 죽초액 $2 \%$ 와 $4 \%$ 급여구가 유의적 $(\mathrm{P}<0.05)$ 으로 감소하였다. 총균수는 죽초액 $2 \%$ 와 $4 \%$ 급여구가 대조구에 유의적 $(\mathrm{p}<0.05)$ 으로 낮게 나타났다. 냄새는 저 장 1 일과 3 일에 죽초액 $2 \%$ 와 $4 \%$ 급여구가 대 조구에 비해 유의적 $(\mathrm{P}<0.05)$ 으로 높은 점수를 받아 돼지 특유의 이취가 감소하는 효과를 나
타냈다. 외관은 저장 1 일에 죽초액 $2 \%$ 와 $4 \%$ 급여구가 대조구에 비해 유의적 $(\mathrm{P}<0.05)$ 으로 증 가함을 나타냈다. 맛은 저장 1 일과 3 일, 6 일에 죽초액 $2 \%$ 와 $4 \%$ 급여구가 대조구에 비해 유 의적 $(\mathrm{P}<0.05)$ 으로 높게 나타났다.

이상의 결과를 종합해보면 죽초액 $2 \%$ 와 $4 \%$ 급여된 돼지고기는 육질특성과 저장안정성이 개선된 것으로 사료된다.

(색인어 : 죽초액, 돼지고기, 육질특성, 지방산 패도, 총균수)

\section{VI. 인 용 문 헌}

1. Akio Yasuhara. 1993. Valatile compounds in pyroligneous lipids from karamatu and chisimasasa. Aagric. Bio. Chem. 51(11):3049.

2. Deymer, D. I. and Vandekerckhove, P. 1979. Compounds determining $\mathrm{pH}$ in dry sausage. Meat Sci., 3, 161.

3. Field, R. A. and Chang, Y. O. 1969. Free amino acids in bovine muscle and their relationship to tenderness. J. Food Sci. 34:329.

4. Hisasi, Yoshmura. 1993. Promoting effect of wood vinegar compounds on the mycelial growth of two basidiomycete. Tran. Myco. Soc. Japan : 141.

5. Ketelaere, A., Demeyer, D., Vandekerckhove, P. and Vervaeke, I. 1974. Stoichimetry of carbohydrtae fementatin during dry sausage, and tenderness of pork, Meat Sci., 32:161.

6. Khan, A. W. and Van den Berg, L. 1964. Some protein change during postmortem tenderization in poultry meat. J. Food Sci. 29:537.

7. Kotula, A. W., Ayres, J. C., Huhtanen, C. N., Stren, N. J., Stringer, W. C. and Tompkin, R. B. 1980. Guidelines for microbiological evaluation of meat. Proc. 33rd Annual Rec. Meat Conf., p. 65.

8. Ledward, D. A. 1984. Haemoproteins in meat and meat products. In developments In Food Protein III, ed. B. J. F. Hudson, Applied Science, London. pp. 33-68.

9. Lizaso, G., Hernadez, B., Chasco, J., Insausti, K., Beriain, M. J. and Purroy, A. 1996. Meat colour from pirenica steers and heifers after vacuum 
packging. Proceedings of the 42nd ICOMST. 1:98.

10. Nottingham, P. M. 1982. Microbiology of carcass meat. In "Meat Microbiology", Brown, M. H. ed.. Applied Science Publishers Ltd., London. p. 13.

11. Palanska, O. and Nosal, V. 1991. Meat quality of bulls and heifers of commercial cross breeds of the improved Slovak Spotted Cattle with the Limousine breed. Vedecke Prace Vyskumnedo Ustaru Zivocisnej Vyroby Nitre(CSFR) 24:59.

12. SAS. 1988. SAS User's Guide : Statistics. SAS Inst., Inc., Cary, NC.

13. Witte, V. C., Krause, G. F. and Baile, M. E. 1970. A new extraction method for determining 2-thiobarbituric acid values of pork and beef during storage. J. Food Sci. 35:582.

14. Yates, L. D., Dutson, T. R., Caldwell, J. and Carpenter, Z. L. 1983. Effect of temperature and $\mathrm{pH}$ on the post-mortem degradation of myofibrillar proteins. Meat Sci., 9:157.

15. 김동희. 1990. 성형 목탄가루가 사료첨가제로서 의 이용가능성에 관한 연구. 건국대학교 석사학 위논문.

16. 김한성, 김성훈. 1998. 목초액의 약리 및 임상 효 능과 연구방향. 대전대학교 한의학연구소 논문 집. $7(1): 831$.

17. 류경선, 이문준, 송근섭, 나종삼, 김종승. 1997. 목탄과 목탄액의 첨가가 육계의 생산성과 육질 에 미치는 영향. 한국가금학회지. 24(3):139.

18. 박구부, 손영달, 김영환, 이한기. 1988. 한국 재래 산양육의 저장기간에 따른 지방.
19. 박우문, 최원희, 유익종, 김왕준, 전기홍, 전동효. 1997. 발효식품에서 분리한 젖산균이 발효소지의 저장중 미생물의 특성에 비치는 영향. 한국축산 학회지. 39:60

20. 석현덕, 장철수, 서영완. 1998. 목질탄화물의 농 축산업적 이용현황과 전망. 목질탄화물(숯과 목 초액)의 농업 및 환경적 이용에 관한 국제 심포 지움. pp. 129-149.

21. 석현덕, 장철수. 1999 . 소경목불량목 등 목질계 폐자원을 이용하여 가공된 목탄.목탄액의 농수 축산업에서의 실용화 및 산업화 연구. 한국농촌 경제연구원. C99-23.

22. 장철수, 석현덕. 2001. 농.축산업분야에 있어서 목탄·목초액 이용의 활성화 방향. 산림경제연 구. 9(1):28.

23. 谷田貝光克. 1990. 木酢液の 精製と利用技術 及び 木炭による 消臭技術. 木炭と木炭液の 新 用述開發研究成果集. p. 297.

24. 福島義信. 1980. 젖소의 위에서 발생하는 VFA와 네카릿치의 투여효과. 일본축산연구 34:773.

25. 松田義夫. 1975. 약물의 해독작용에 관한 연구. The Clinical Report. 9(13).

26. 永田耕一。1983. 肝實質性黃疸における天然樹 液の臨床的檢討. The Clinincal Report. 17(11): 231.

27. 田村豊辛. 1975. 약물의 해독작용에 관한 연구 (제8보) Holyessig를 포함하는 나무껍질 성분에 대한 연구. The Clinical Report. 9:3346.

(접수일자 : 2002. 8. 16 / 채택일자 : 2003. 3. 5) 